\title{
The development of Nyonya cuisine in the Malay Archipelago: Penang and Malacca Nyonya cuisine
}

\author{
Youri Oh ${ }^{1,2^{*}}$ D, Nurul Fatin Afiqah Hj Abdul Razak ${ }^{3}$, Donovan Hee Tat Wee ${ }^{4}$, Eric Lu Ching ${ }^{5}$ and Zubaidah Rahman ${ }^{6}$
}

\begin{abstract}
Nyonya cuisine is widely spread in the Malay Archipelago which is known as fusion of Chinese immigrant and local Malay cuisine. The cuisine has been established and developed with globalisation and movement of people in the region. Furthermore, it is identified as cultural product or image of the society which represents the identity of the people in the society. This study is to understand the establishment and development of Nyonya cuisine in line with the migration of the Peranakans in the Malay Archipelago via the exiting literatures. Data collected are from secondary sources, derived from relevant literatures, media and academic articles and authorised websites relevant to Nyonya cuisine and the Peranakans in the Malay Archipelago. The authors' observation is also used to grasp the distinction in Nyonya cuisine. As results, Nyonya cuisine is a representative result of cultural hybridisation by migration of the Peranakans into the Malay Archipelago, geographical proximity and political factors. Nyonya cuisine today is further developing along with the influx of global culture into the region which fosters rejuvenation and exchange of cuisine.
\end{abstract}

Keywords: Nyonya cuisine, Peranakans, Food culture, Malay Archipelago

\section{Introduction}

By the spread of globalisation, the world becomes more integrated and movement of people across the borders seems more frequent than ever. Not only people but also their culture and ideas across the borders have led to a spread of immigrants' culture into the destination society [1]. Cuisine has become a definite subject that should not be ignored in this global movement as it has spread worldwide by the flow of immigrants. Food for humans was only to provide nutrients to survive in the beginning of human beings' history. Obtaining food and cooking were a chore or a core living process, such as breathing. Over the course of history, food has evolved into a sort of 'cultural image' that represents the people and regional identity as 'eating is a daily reaffirmation of cultural identity [2]'. Preparing and presenting 'culture image' created such table manners, recipe and art form that give further distinctive features of the cuisine. This contributes to a popular saying 'you are what you eat' meaning the food that you eat represents and defines you [3]. Thus, food culture explains and reinforces society or people's identity [4]. The cuisine is a cultural product established and further developed by cultural process [5]. In regional context, the Malay Archipelago has been perceived as 'melting pot' of the region because of a huge number of immigrants from different cultural backgrounds [6], and became a cosmopolitan metropolis today with its multicultural population of

* Correspondence: youri_oh@hotmail.com

${ }^{1}$ Faculty of Arts and Social Science, University of New South Wales, Kensington, Australia

${ }^{2}$ Bandar Seri Begawan, Brunei Darussalam

Full list of author information is available at the end of the article

(C) The Author(s). 2019 Open Access This article is distributed under the terms of the Creative Commons Attribution 4.0 International License (http://creativecommons.org/licenses/by/4.0/), which permits unrestricted use, distribution, and reproduction in any medium, provided you give appropriate credit to the original author(s) and the source, provide a link to the Creative Commons license, and indicate if changes were made. The Creative Commons Public Domain Dedication waiver (http://creativecommons.org/publicdomain/zero/1.0/) applies to the data made available in this article, unless otherwise stated. 
the society. Nyonya cuisine is described as the cuisine which blends Chinese cooking ingredients and recipes with Indo-Malay flavours, herbs and spices [7]. In other words, Nyonya cuisine is a product of cultural process evoked by globalisation and global migration movement and has widely spread in the Malay Archipelago that became a fusion of local cuisine and migrants' cuisine.

\section{Methodology}

This article endeavours to explore the development ${ }^{1}$ and spread of Nyonya cuisine in a link with migration of the Peranakans, who are Chinese immigrants to Southeast Asia region, particularly to the Malay Archipelago, based on data collected from secondary sources, mainly derived from relevant literatures, academic articles and authorised websites with regard to Nyonya cuisine and the Peranakans in the Malay Archipelago. The authors' past experience and observation were also used to grasp the distinction in Nyonya cuisine in this article. The objectives of this article are (1) to explore the history of the Peranakans and Nyonya cuisine, (2) to investigate distinctive features of Nyonya cuisine in brief and (3) to find out the current status of Nyonya cuisine in the region and the regional differences, particularly focuses on Malacca and Penang.

\section{History of the Peranakans and Nyonya cuisine \\ Origin of the Peranakans}

Along with the migration movement, a mixture of immigrants' and host country's culture sometimes will give birth to a modified or new culture along with new practices, beliefs and food. The relationship between the Peranakans and Nyonya cuisine is an example of the creation and hybridisation of a new vibrant culture [8].

'Peranakan' refers to 'descendant' in Bahasa Melayu, and it particularly identifies Chinese immigrants and their descendants from mainland China to Malay Peninsula, including the Malacca Sultanate, during the fifteenth to seventeenth century $[5,9,10]$. The term is best described as 'Chinese with Southeast Asian influences, particularly in regard to their language variety, Baba Malay' [15]. Male Peranakans are known as Baba, while female Peranakans are known as Nyonya. Some Peranakans from Malacca started to migrate and form new Peranakan enclaves in

\footnotetext{
${ }^{1}$ Development, in general, is best understood as a process that has established and evolved throughout history upon the aims for better improvements. However, the term has been defined in many ways by different perspectives. Among the different definition and elements that have been discussed in order to define the term in the existing literatures, this study uses the term of which covers history [11-13] and modernization [14]. This study used the term 'development' as a concept to cover the establishment, history, modernisation and the current trend of Nyonya cuisine based on the existing literatures, not to provide a new perception of the cuisine by authors' perspectives.
}

Singapore and Penang during the British colonisation in the mid-eighteenth to nineteenth century [16]. The Peranakans were educated in English-speaking countries during the nineteenth to early-twentieth century and thus were fluent in speaking two or more languages such as English, Bahasa Melayu and Chinese of which many were engaged as leader of communities $[17,18]$ and were allowed to have considerable wealth and high status during the colonial times.

Despite their inter-racial marriages with the strait Malays, most Peranakans are not Muslim which enables them to retain their ancestry and religion as there were no laws requiring them to convert, and after a few generations, many Peranakans desire endogamous marriages which means they prefer to marry other Peranakans [19]. Due to the retainment of their ancestral identities, they celebrate major Chinese celebrations such as Lunar New Year and the Lantern Festival [20]. There are traces of Dutch, Portuguese and British influences found in Peranakans [21]. However, their ancestral identities and Malay influences give the most remarkable influence on Peranakan culture [22]. At present, the Peranakans are identified via self-acknowledgement and their tangible culture such as cuisines and clothing [19]. Malacca, Penang and Singapore are the three main distinct locations where the Peranakan heritage is firmly established today.

\section{Nyonya cuisine}

The Peranakans could not inherit their traditional dishes after their settlement in destination due to unavailability of certain ingredients; as a result, they had to improvise with the local ingredients [23] that they have assimilated into the local environment. In addition, the interracial marriages between the immigrant Chinese and locals (Malays) are bound to create some fusion dishes. Some defines Nyonya cuisine as preparing dishes using Chinese technique such as wok-frying and pork, with Malay and Chinese spices and flavours [5, 24]. Examples of ingredients derived from the Chinese culture are black mushrooms, fungus such as bok jee (wood ears), kim chiam (lily buds), taukee (soybean sticks), fish maws, tanghoon (glass noodles), beehoon (rice vermicelli) and different varieties of seasonings such as tauchio/taucheo (salted soybean paste) and tichio (sweet sauce) [5]. The most distinctive spice in both Nyonya and Malay cuisines is chilli, which can be used in both fresh and dried forms followed by others such as serai (lemon grass) and flower buds such as bunga kantan (torch ginger buds), as well as fruits, nuts and seeds, specifically buah keras (candlenuts), buah keluak (a large black nut), lime juice, asam Jawa (tamarind), cinnamon, cloves, nutmeg and ketumbar (coriander seeds) $[5,19]$. 
In the past, Peranakans followed the strict traditions of their Chinese ancestry where the womenfolk of a household were confined to their respective houses most of the time [19]. Therefore, Peranakan women spent most of their time mainly in the kitchen of the house since it was said the kitchen was the heart of life and activity of a house at that time. And their cooking ability was judged and standardised the worth of women in the community [5]. As mentioned earlier, most Peranakans were relatively wealthy that many households were able to employ several servants and maids. With a considerable amount of free time and helping hands, Peranakan women had resources to experiment and refine their way of cooking, which contributed to the development of Nyonya cuisine. Few examples of famous Nyonya cuisine are Ayam buah Keluak, Penang Asam Laksa, Ayam Pongteh, Achar, fish head curry and prawn chilli paste. These dishes were improvised using the spices such as tamarind and keluak found in the Malay Archipelago [23].

Recipes of Nyonya cuisine are handed down to the next-generation that uphold and inherit traditional recipes from the previous generations. Women play a major role in Nyonya cuisine as the role of Peranakan womenfolks was mostly confined to kitchen and house works. The assimilation and hybridisation of Peranakans in the Malay Archipelago created Nyonya cuisine by their efforts to overcome and adapt local culture and environment. The similarities of ingredients, food preparation and cooking of Nyonya cuisine to Chinese and Malay or Indo cuisine are clear evidence that Nyonya cuisine is a product of cultural process that assimilated and borrowed local cuisine into Peranakan cuisine, and further developed and established hybridised cuisine in the Malay Archipelago.

\section{Discussion}

The Peranakans in Penang and Malacca and Nyonya cuisine

Penang and Malacca were known as commercial areas in Malaysia where the Peranakans are prominently populated. Chinese male immigrants' consistent movement to Penang and Malacca and their intermarriage with local women [15] led eminent number of the Peranakan population in both areas. Penang is located near to the border of Thailand, while Malacca is located further south, near Indonesia (see Fig. 1). Such geographical proximity has highly influenced the establishment of the cuisine in Penang and Malacca. The Peranakans have shared and practiced distinctive lifestyle which hybridises local and Chinese culture. However, difference between the Peranakan culture of Penang and Malacca is notable in their food and language [16].

The proportion of Hokkien and Malay language usage gives language distinction between the Malacca and Penang Peranakans. The Malacca Peranakans speak Baba Malay, a language that is a creolised Bahasa Melayu with borrowing Hokkien and English words [24]. In addition, Malacca was the centre of the Sultanate Melaka and its dominant regional population has been Malay since their settlement in the fifteenth century, while Penang was an environs of another Malay population and was considered small [25], which have added strong influence in the frequent usage of Bahasa Melayu in Malacca. The Penang Peranakans speak Baba Hokkien, which is based on Hokkien with slang of Bahasa Melayu and expression [5, 26].

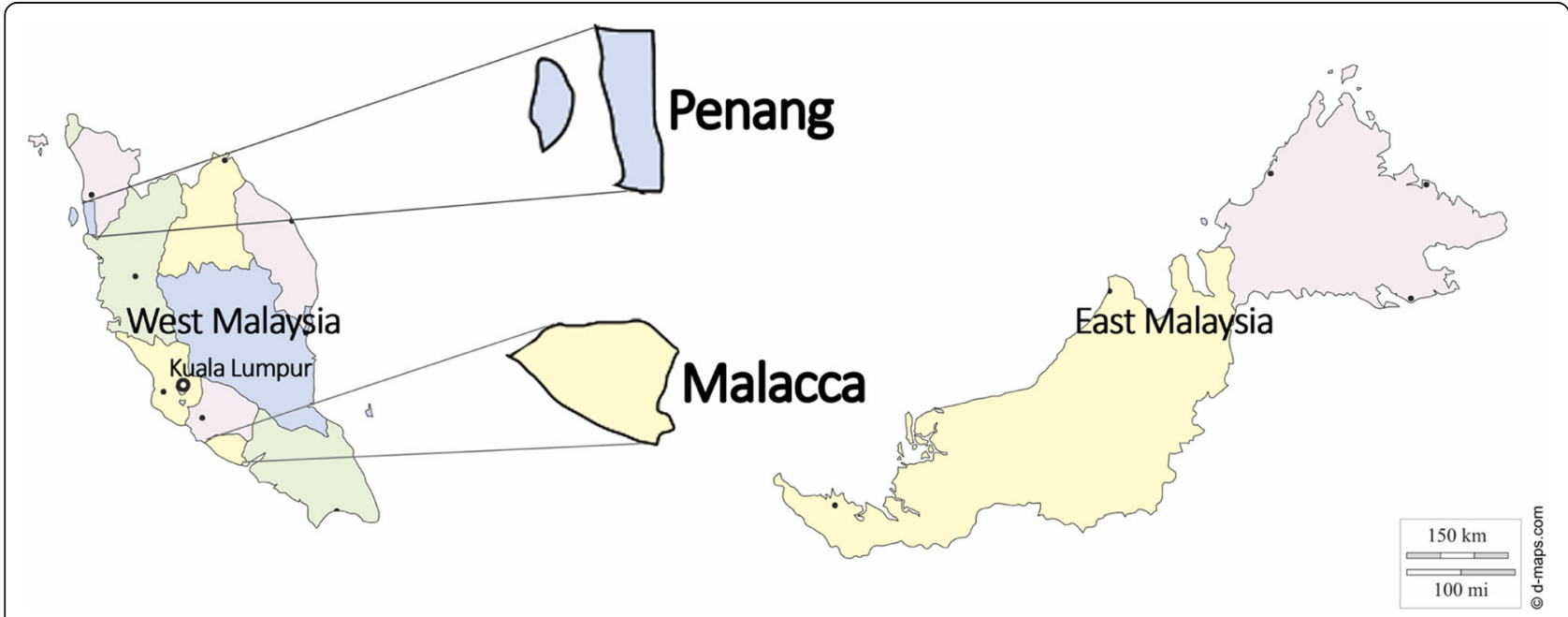

Fig. 1 Location of Penang and Malacca. Penang and Malacca are located in the West Malaysia. Both states are located along the north-west coast of the Malacca Strait. Penang and Malacca are called 'melting pot' of culture and tradition because of the influx of immigrants particularly Chinese, Malay, Indian and other remnants of English colonialism. Malacca is also well-known as a diverse cultural and traditional society and often called as "Small Penang" because of the similarity of the city to Penang 
Differences can be found in both regions' cuisines although they are within the category of Nyonya cuisine. It is considered that Nyonya cuisine is originated from Malacca by the first settlement of Strait-Chinese to Malay Peninsula that dispersed to Penang and Singapore during the British colonisation in the mideighteenth to nineteenth century [16]. Geographical divergence and proximity can re-invent or blend the cuisine in each region; Malacca Nyonya cuisine is mostly influenced by the Portuguese and Indonesian, whereas Penang is highly influenced by Thailand [27, 31]. The distinction is clearly shown in each region's dominant ingredients, recipe and utensils [28]. Laksa, a renowned dish of Nyonya cuisine, provide clear differences between
Penang and Malacca Nyonya cuisine. The ingredients of Laksa in Penang and Malacca show differences as Penang Laksa (see Figs. 2a, b and 3) mainly uses lime, chilli, herbs, shrimp paste and tamarind which gives sour and tangy flavour which is also known as 'Assam Laksa', while Malacca (curry) Laksa (see Figs. 4 and 5) uses Malaysian local herbs such as cumin, belachan, chilli and coconut milk that has sweeter flavour and illustrates more curry-like noodle soup [29-33].

The cooking recipe also shows slight differences. Otak-otak (see Figs. 6 and 7) is a custard kind of snack made of fish, egg, belachan, coconut milk, lime juice and other ingredients wrapped by leaf. Malacca otak-otak is narrowly wrapped with coconut or nipa leaves then
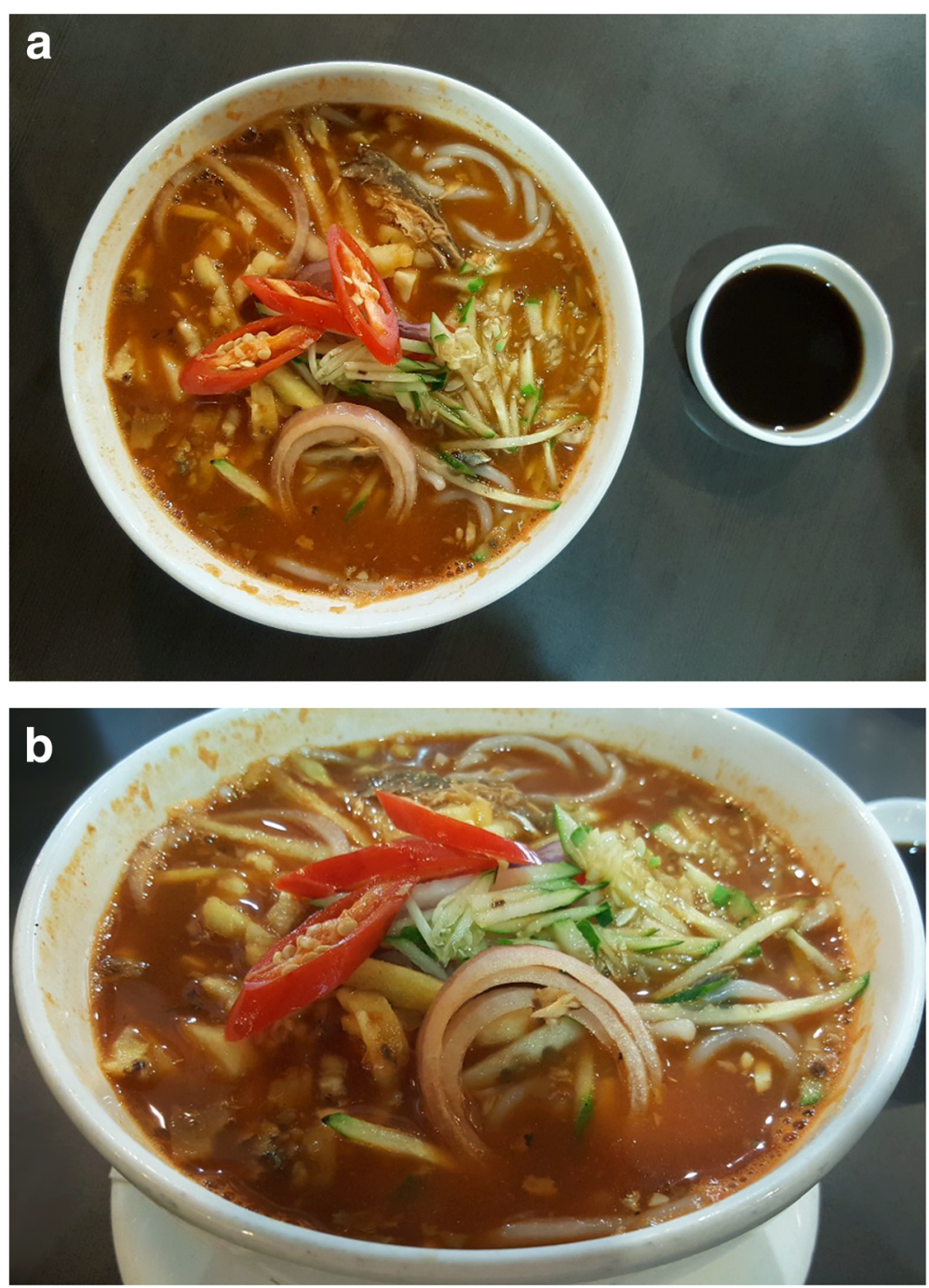

Fig. 2 a, b Penang Laksa (Assam Laksa). Penang Laksa is as known as 'Assam Laksa'. The dish was born in Penang with fresh fish-based broth and bunch of herbs and vegetables. The dish has a sour taste by the use of lime, chilli, galangal, tamarind and local herbs and also tangy by fish (usually mackerel or sardine or ikan tonkol (skip jack tuna)) broth and shrimp paste. It is garnished by shallot and other sliced raw vegetables such as cucumber, onion and chilli. The dish is served with heh ko (dark shrimp sauce)—dark sauce displayed on the right of the Assam Laksa in the figure 


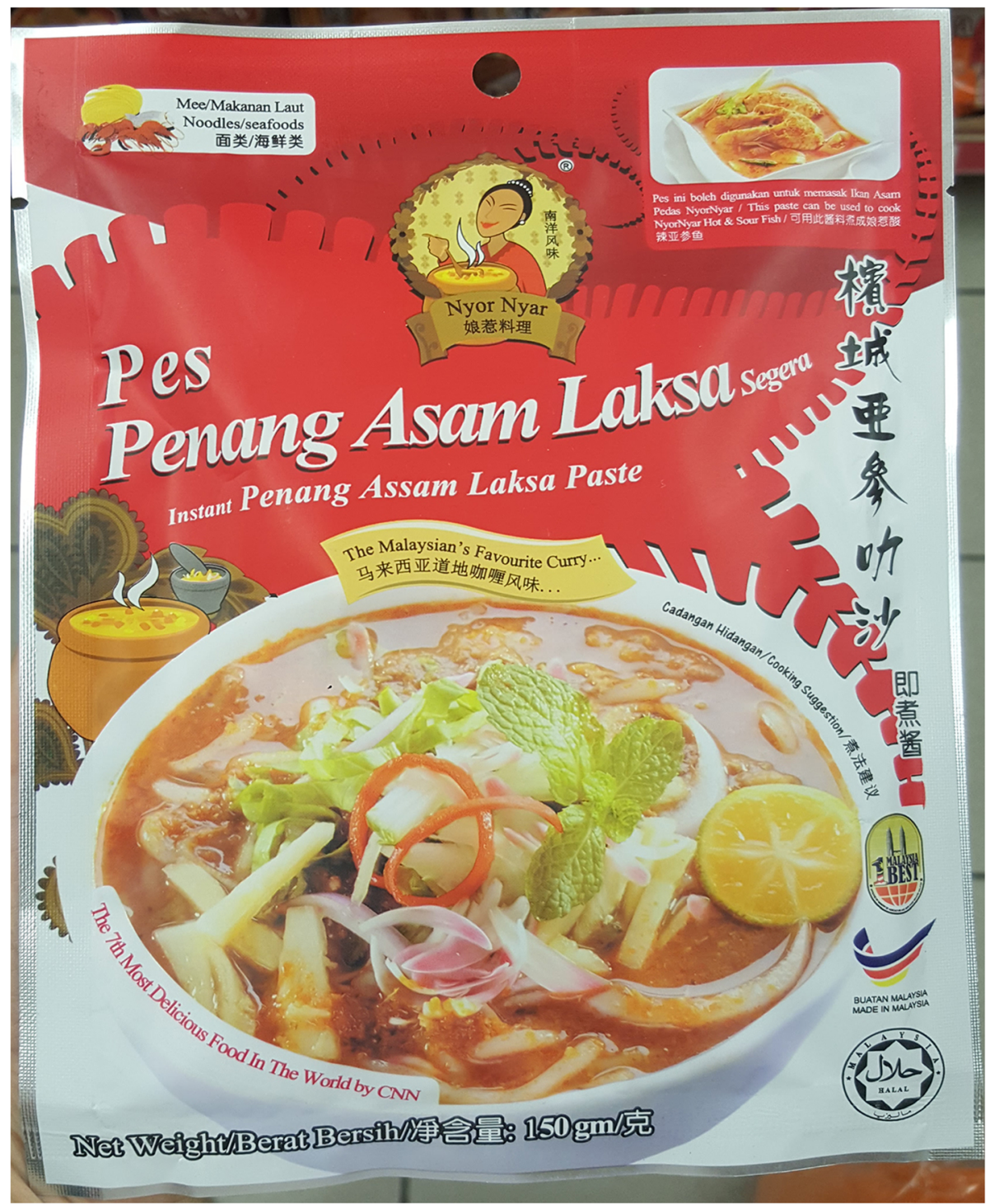

Fig. 3 Penang Laksa Paste at grocery store in Malaysia. Penang (Assam) Laksa paste can be easily found in grocery stores in Malaysia. There are varieties of products manufactured and sold in Malaysia which ease the preparation of the dish. The ingredients of the paste products contain fish (vary) broth, vegetable and herbs in general that consumers only need to add water to the paste, boil noodles and add garnishes and vegetables upon the preference of consumers

grilled over charcoal fire to enclose smoky flavour and smell [5, 34]. Penang otak-otak is mixed with betel leaves and wrapped with banana leaves in square-bowl shape or pocket shape fastened on the upper side with a toothpick. Penang otak-otak is steamed that gives softer texture, while Malacca's have a strong smoky smell and flavour [34] and firm texture after being grilled over charcoal fire.

Besides, there are differences in significant Nyonya dish in each region by adaptation of Nyonya cuisine. Buah Keluak (Indonesian black nut dishes) is still a famous dish in Malacca, but in Penang, due to strenuous preparation and particular taste, the dish has disappeared in the region [35]. Belachan (shrimp paste) in Malacca has more mashed texture and paler colour while Penang belachan (also known as hae ko) is a dark black sticky paste that is used for salad dressing [36, 37]. The Penang Peranakans are more open and receptive to new culture and environment [38]. As mentioned above, geographical proximity of Penang to Thailand builds more interaction between Penang and Thailand that created remarkable dish in Penang Nyonya cuisine, such as kerabu salad (spicy pineapple salad) - kerabu is originated from Thailand. Nyonya kuih (also called as Kuih ko sui/swee) is also a famous Penang Nyonya cuisine [22] that is steamed in Chinese teacups. 

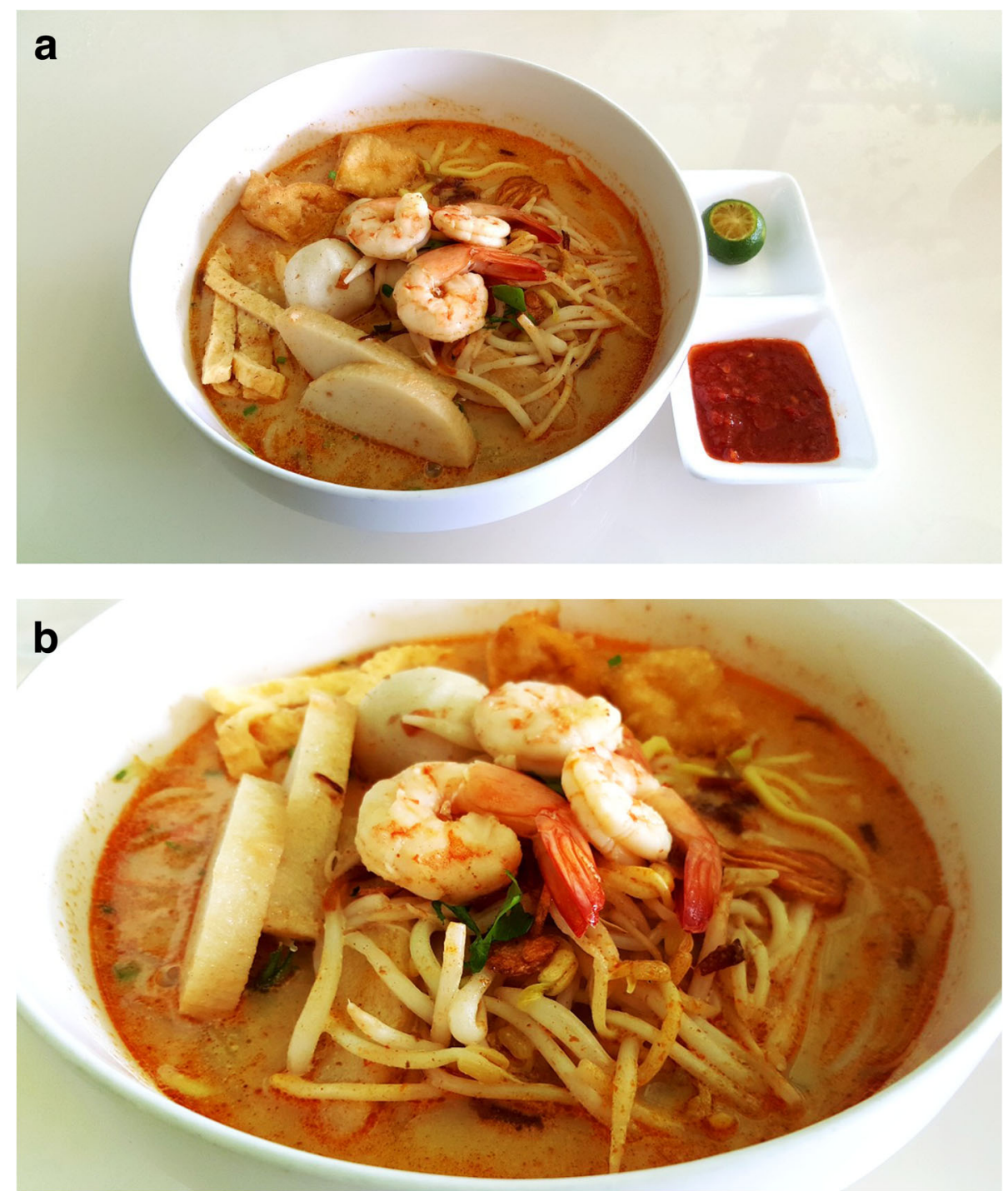

Fig. 4 a, b Malacca Laksa (curry Laksa). Malacca Laksa used coconut milk which provides thick texture in the soup base. It is relatively sweet, spicy, and creamy and contains curry taste as the dish. The dish is known for the strong flavour by several ingredients used for the dish such as chicken and/or prawn, curry powder, fish balls, fried tofu, chillies, shrimp paste, garlic, ginger, cumin and local ingredients. Often garnished by bean sprout, shredded chicken and prawn and served with sambal that enhances the flavour of the dish

\section{Effects of globalisation - the downfall of Nyonya cuisine and dilution of Nyonya identity}

It is widely accepted that the downfall of the Peranakans started in the early twentieth century due to political factor such as the world wars. It depleted the Peranakans of their massive wealth, further contributed by the decline in value of rubber and tin. Some of the wealth was squandered away by the younger generations who basically live off their descendant's savings. Some of the wealth was donated to help rejuvenate the crippled economy of the Malay Archipelago due to the world wars and to help their colonial British bosses in some cases. The withdrawal of the colonial British and independence of Malaysia and Singapore further weakened the Peranakans, stripping them of their special social status and privileges as well as their sense of identity. Furthermore, the decisions of the Malaysian and Singaporean Government to classify people into strict rigid categories by race-as Malay, Chinese, Indian and others-has further diluted the Peranakans' identity. With globalisation, people tend to integrate their cultures with others more, modify or outright replace old traditions and practices in favour of making it easier or cheaper. This means that certain lavish Peranakan practices such as the 12 days wedding rituals were either reduced or abandoned in favour of simpler and cheaper ceremonies. As education becomes more widely available, the younger generations of Peranakan are tempted to choose not to learn the old method as it is usually time consuming and labour-intensive. Also, with a good 


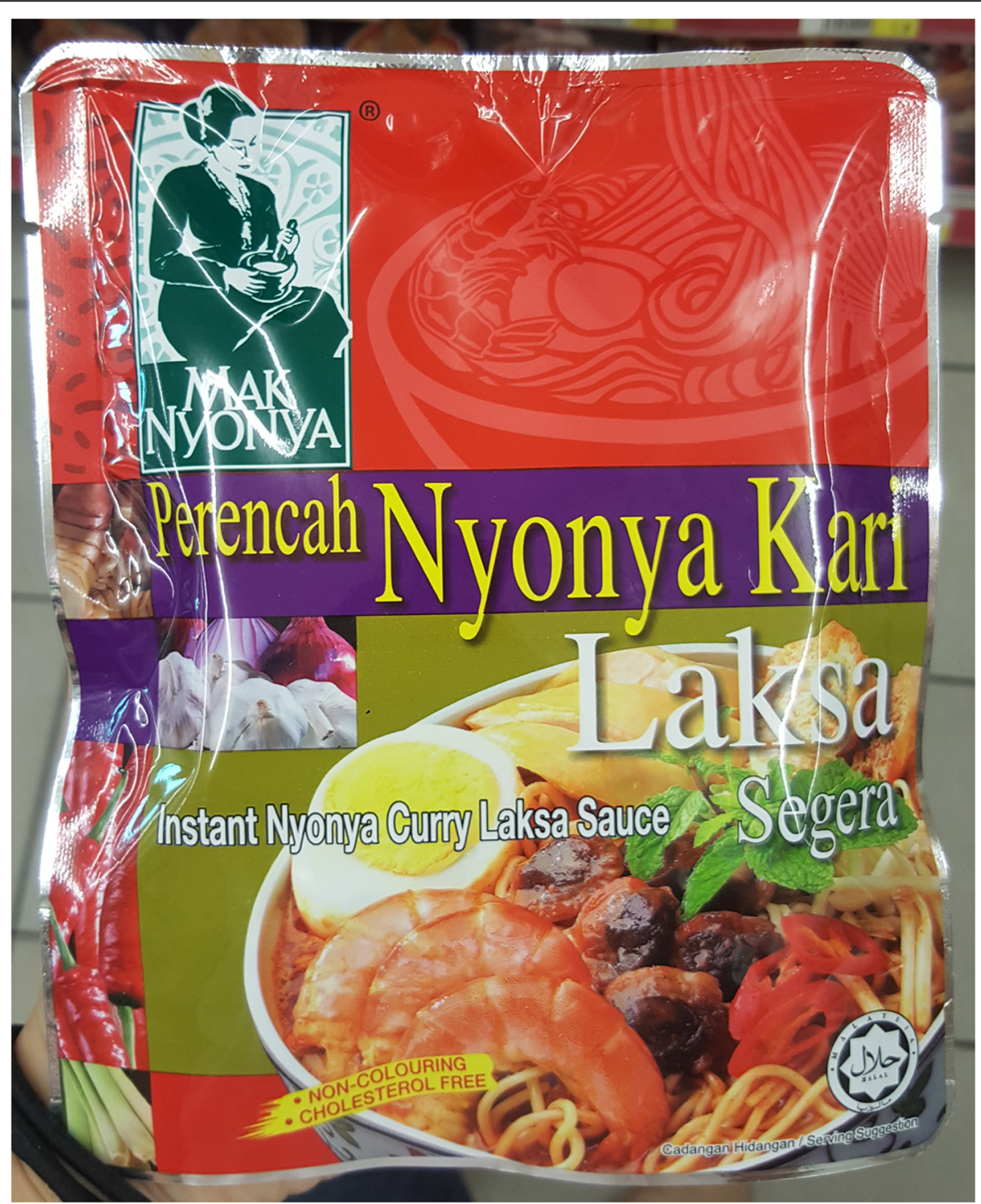

Fig. 5 Malacca Curry Laksa paste at grocery store in Malaysia. Malacca Curry Laksa paste is also easily found in grocery stores in Malaysia. The paste blended the main ingredients of Malacca Curry Laksa, which contains curry powder, shrimp paste, herbs and vegetables that ease the preparation of the dish. Such paste products only request consumers to add water to make easy broth of the dish, noodles, vegetables and garnishes upon the preference of consumers

education, they have a wider range of jobs to choose from instead of sticking to the old professions. As with any cultures, Peranakan also practices taboos or 'pantang larang' but most of the modern generation no longer does this mainly either it is too time consuming or it is not a big deal for them. This also means traditional Nyonya cuisines that are generally time consuming were practiced less and less due to declining interests of the young generation. Finally, the Peranakans have only few ways to express their heritage, mainly through their clothing and food in modern times [19]. The older generation of the Peranakans nowadays sees their cultural identity as diminishing in that there is a degree of 'Peranakan-ness' within the society in terms of language fluency by Peranakans in the late 1960s: 'I don't really think there is a Peranakan identity these days; it's more like an open culture for everyone'.-Mr. Tan, an older generation of Peranakans [39].

\section{The rejuvenation of Peranakan culture}

In the 1980s, the Peranakan culture started to gain back the public interests. In Singapore, films and drama series such as Pileh Menantu's Choosing a Daughter-inLaw (1984), The Old Husband and The Young Wife (1985) and The Little Nyonya (2008) contributed to gain public attention on the Nyonya culture. Cookbooks illustrating Nyonya cuisine helped to resurrect 


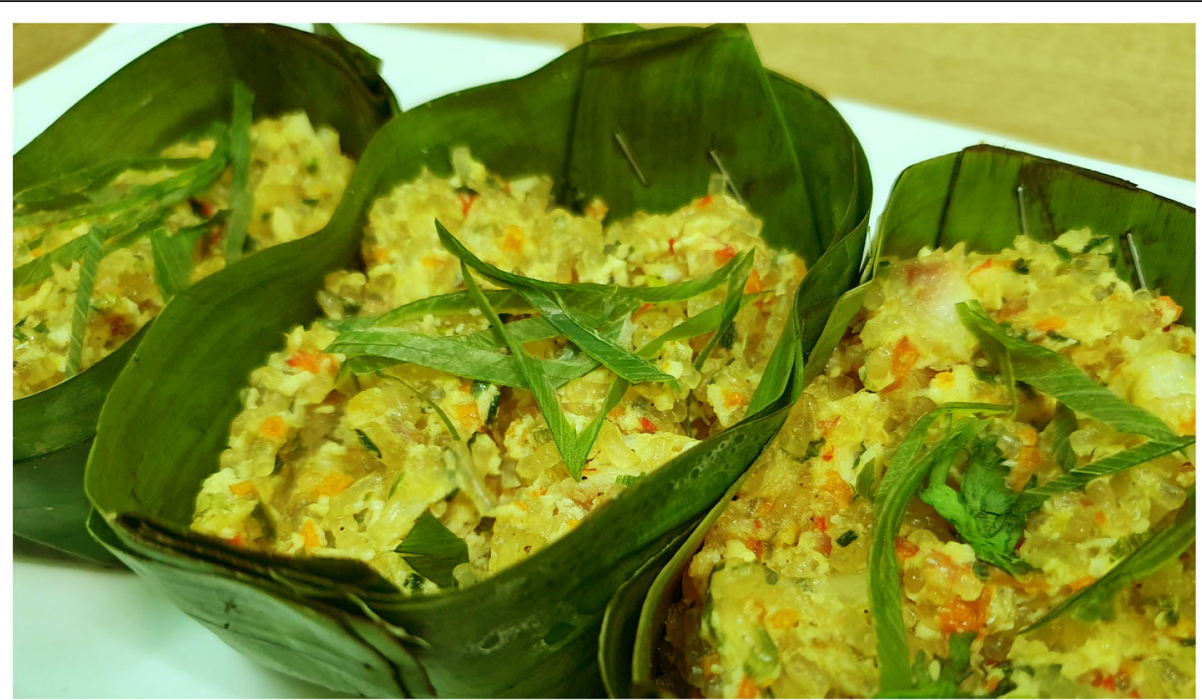

Fig. 6 Penang otak-otak. Penang otak-otak is a soft-textured snack. It is made of fish, egg, coconut milk, lime or lemon juice, belachan, betal leaves, herbs and other ingredients that are wrapped by banana leaf. The shape of bowl vary as it depends on personal preference; however, it is often either squared-shape or pocket shape fastened on the upper side with a toothpick. The dish is ideally steamed for 10 to 20 min in high heat and serves as a snack or side meal of the main dish

and keep the cuisine alive as well. One of the most representative Nyonya cookbooks was Mrs. Lee Chin Koon's (mother of Lee Kuan Yew) Mrs. Lee Cookbook (Vol.1 in 2003 and Vol.2 in 2004).

In Malaysia, several books on Peranakan community were published. Yeap Joo Kim's The Patriarch (1975), Ruth Ho's Rainbow Round My Shoulder (1975) and Lee Su Kim's Malaysian Flavours $(1996,2004)$ are representative publication accounts of Peranakan culture [19]. The book Nyonya kebaya (2004) and exhibition by Datin Seri Endon Mahmood, the previous First Lady of Malaysia, contributed to have great attention of public in 2000s. Nyonya restaurants continue to appear in Malaysia due to their unique flavours [19] which sustain Nyonya cuisine in society.

Despite the rich heritage Nyonya cuisine carries, young population in the region do not seem to be aware of the cuisine. Young university students majoring culinary arts are only aware of the culture of the cuisine, not the uniqueness or details of the cuisine that the efforts made by media and publications seem nominal unless the young person does not have a strong Peranakan family background [40].

There has been an increase of curiosity and contribution of Nyonya cuisine in regions' cookbooks, blogs,

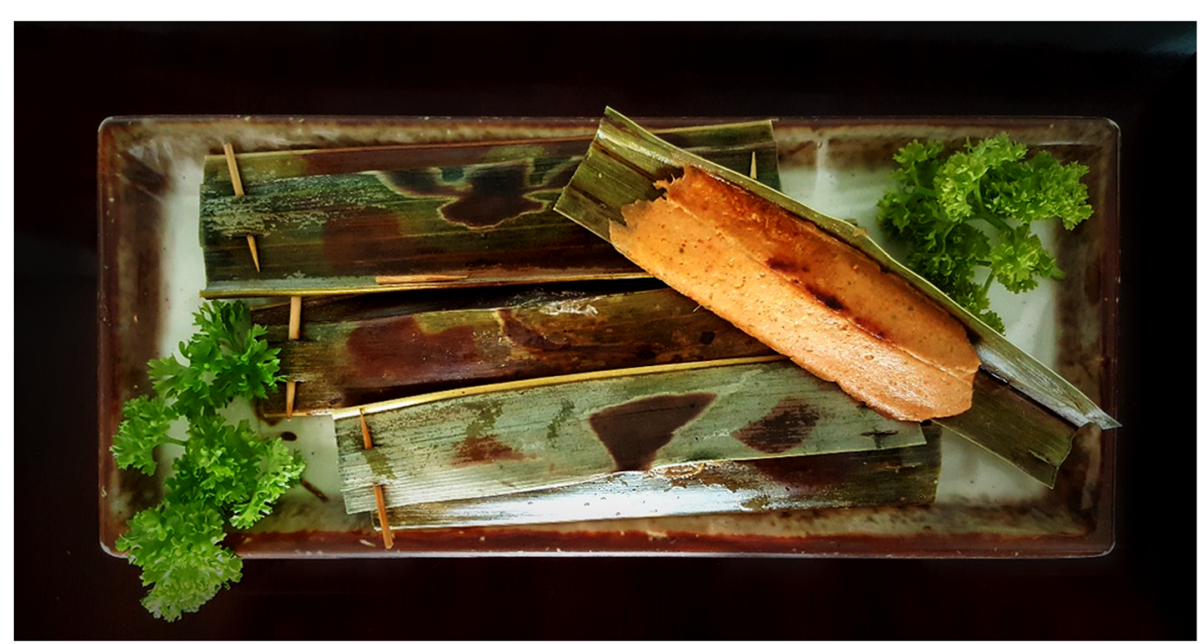

Fig. 7 Malacca otak-otak. Malacca otak-otak is custard-textured snack made of fish, egg, coconut milk, lime or lemon juice and other ingredients wrapped by coconut or nipa leaves. Malacca-style otak-otak is grilled over charcoal fire in order to enclose smoky taste and smell. Although it is soft after grilled over charcoal fire, Malacca's tend to have more firm texture than Penang otak-otak 


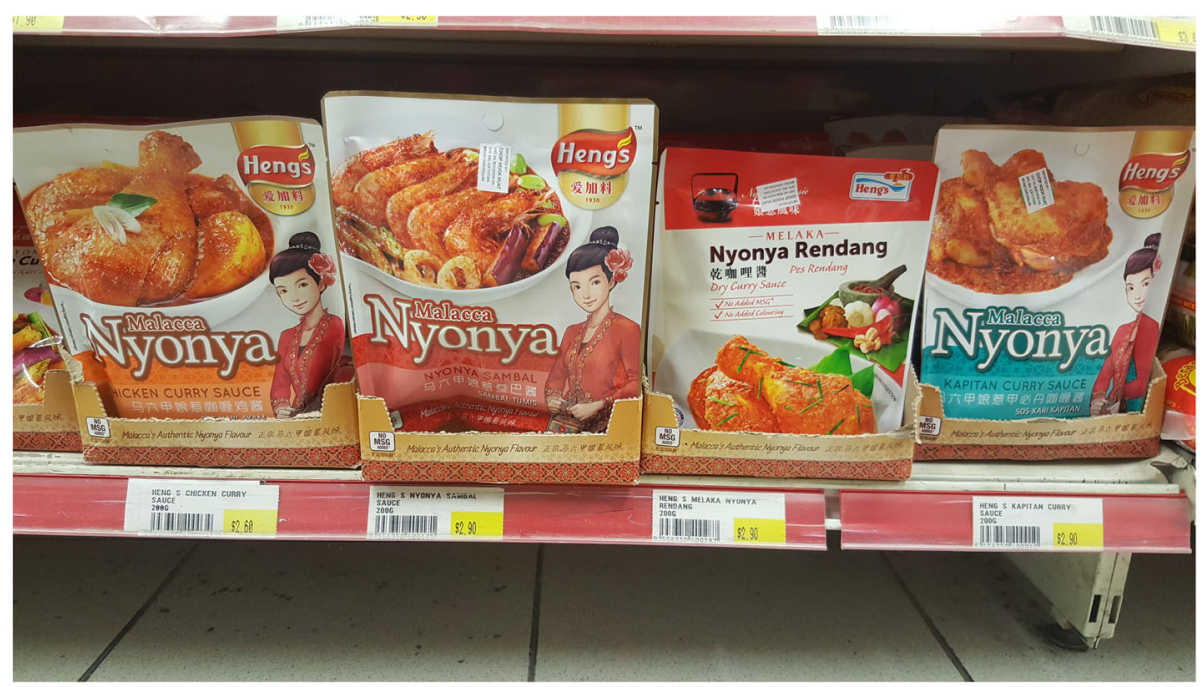

Fig. 8 Nyonya food products at a grocery store in Malaysia. Nyonya food is a distinctive local cuisine in Malaysia, and there are many food products manufactured and sold in local grocery stores. The significance of Nyonya food is then easily found in local community by various food products in groceries and restaurants in Malaysia. Apart from Nyonya Laksa and otak-otak as introduced above, rendang, curry sauce, sambal and many more food products are produced in Malaysia and beloved by locals

online websites and food product which sustains public interest towards Nyonya cuisine [41]. The annual convention of Baba Nyonya hosted by the State Chinese Association (Peranakan communities) in Southeast Asia rotates among Penang, Melacca, Phuket and Singapore [42] and also contributes to promoting the cuisine and Nyonya culture in the region. Nyonya food product (see Fig. 8) manufactured by local companies such as instant noodle and laksa paste are highly consumed and enjoyed popularity among locals. Such contribution and support by Peranakan communities and the public appear to be the motive for the rejuvenation of Nyonya cuisine in the present era.

\section{Conclusion}

The purpose of this article was to provide a good understanding of the Nyonya cuisine history throughout the history of the Peranakans, to investigate the feature and development of the Nyonya cuisine in the Malay Archipelago and to understand the present status of Nyonya cuisine in the region. Nyonya cuisine was born out as a unique mixture of cultures along with the movement of the Peranakans from China to the Malay Archipelago. Chinese cuisine has evolved and adapted to local cuisine with the transmission of its traditional ingredients which has created new distinctive cuisine in the region. Migration gave significant impacts on the development of regional culture and globalisation and, at the same time, has both positive and negative impacts. It has diluted Peranakan culture by influx of global culture into the region that enables the exchange of culture, while it also assists to rejuvenate the culture by spotlighting and promoting of the culture worldwide. Besides, geographical proximity and political factors also influenced the development of the cuisine in different region of the Malay Archipelago as shown in Penang and Malacca within the category of Nyonya cuisine. By acknowledging the development of Nyonya cuisine since its emergence, it is a distinguished example of cultural hybridisation evoked by a consequence of migrations. The difference between Penang and Malacca Nyonya cuisine shows how geographical proximity, environment and politics influenced the development of the cuisine as Nyonya cuisine differentiated between Penang and Malacca. The tradition of Nyonya culture has been diminished by the strong influence of globalisation into the society. However, the efforts to rejuvenate Nyonya culture intrigued by the public and Peranakan communities via publication, media, campaigns and supports may bring further development of Nyonya cuisine.

\section{Acknowledgements}

The authors appreciate Universiti Brunei Darussalam which made this study possible. And the authors acknowledge Dr. Siti Mazidah binti Haji Mohammad, Universiti Brunei Darussalam, Brunei Darussalam, for her feedback and suggestion in the study.

Authors' contributions

All authors have contributed equally in developing the design, data acquisition, analysis, drafting of the manuscript, discussion and conclusion of this article. All authors read and approved the final manuscript.

\section{Funding}

This research did not receive any specific grant from funding agencies in the public, commercial or not-for-profit sectors. 


\section{Availability of data and materials}

All data and materials used in this article are correctly referenced following the guideline of the Journal of Ethnic Foods and can be found in the reference section.

\section{Competing interests}

The authors declare that they have no competing interests.

\section{Author details}

'Faculty of Arts and Social Science, University of New South Wales, Kensington, Australia. ${ }^{2}$ Bandar Seri Begawan, Brunei Darussalam. ${ }^{3}$ Faculty of Geosciences, Utrecht University, Utrecht, Netherlands. ${ }^{4}$ KCA Deutag, Kuala Belait, Brunei Darussalam. ${ }^{5}$ LeVoeu Company, Bandar Seri Begawan, Brunei Darussalam. ${ }^{6}$ Kaleidoscope Studio, Bandar Seri Begawan, Brunei Darussalam.

\section{Received: 14 December 2018 Accepted: 4 September 2019}

\section{Published online: 20 November 2019}

\section{References}

1. Cohen JH, Sirkeci I. Cultures of migration: the global nature of contemporary mobility. Austin: University of Texas Press; 2011.

2. Kittler PG, Sucher KP, Nelms MN. Food and culture. 6th ed. Belmont: Wadsworth; 2012.

3. Almerico GM. Food and identity: food studies, cultural, and personal identity. J Int Bus Cult Stud. 2014;8:1-7.

4. Miller d. Consumption as the vanguard of history. In: Miller D, editor. Acknowledging consumption. London: Routledge; 1995. p. 1-57.

5. $\mathrm{Ng} \mathrm{CY}$, Karim SA. Historical and contemporary perspectives of the Nyonya food culture in Malaysia. J Ethnic Foods. 2016;3(2):93-106.

6. Dasgupta A, Singh NS. Building "nostalgia" communities: South Asian migrant workers in Malaysia. Econ Polit Wkly. 2015;50(24). https://www.epw. in/journal/2015/24/web-exclusives/building-nostalgia-communities.html. Accessed 10 Nov 2018

7. Hall H. A unique blend: how a surge in the Chinese population influenced Singaporean-Malay cuisine. 2013. http://oivietnam.com/2013/10/a-uniqueblend. Accessed 20 Sept 2018.

8. Kong L. Food in Southeast Asia: heritage, hybridity and contestation. ASEANFocus. 2019;2:16-7.

9. Tan CB. Chinese Peranakan heritage in Malaysia and Singapore. Kuala Lumpur: Fajar Bakti; 1993.

10. West BA. Encyclopedia of the peoples of Asia and Oceania. New York: Infobase Publishing; 2009.

11. Nisbet R. Social change and history: aspects of the Western theory of development. New York: Oxford University Press; 1969.

12. Nisbet R. History of the idea of progress. New York: Basic Books; 1980

13. Cullather N. Development? It's history. Dipl Hist. 2000;24(4):641-53.

14. Ir JS, Quintella RH. Development: an analysis of concepts, measurement and indicators. Braz Adm Rev. 2008:5(2):104-24.

15. Ansaldo U, Lim L, Mufwene SS. The sociolinguistic history of the Peranakans: what it tells us about 'creolization'. In: Matthew S, Lim L, Ansaldo U, editors. Deconstructing creole. Amsterdam: John Benjamins Pulishing Company; 2007. p. 203-26.

16. Ong JT. The pearl and the lion. The Peranakan, vol. 2; 2012. p. 9.

17. Khoo JE. The straits Chinese: a cultural history. Amsterdam: The Pepin Press; 1996.

18. Koh J. Peranakan (Strait Chinese) community. 2013. http://eresources.nlb.gov. sg/infopedia/articles/SIP_2013-08-30_181745.html. Accessed 10 Nov 2018.

19. Lee SK. The Peranakan Baba Nyonya culture: resurgence or disappearance? Sari. 2008:26:161-70

20. Wan EL. Strait born Chinese: the Peranakan story. 2001. http://thingsasian. com/story/straits-born-chinese-peranakan-story. Accessed 15 Oct 2018

21. Ooi KG. Southeast Asia: a historical encyclopedia, from Angkor Wat to East Timor. USA: ABC-CLIO Inc; 2004

22. Kee MY. Chinese porcelain: vibrant festive ware of the straits Chinese. Singapore: Tuttle Publishing; 2009.

23. Tan CB. Food and ethnicity with reference to the Chinese in Malaysia. In: David Y, Wu H, Tan CB, editors. Changing Chinese foodways in Asia. Hong Kong: Chinese University Press; 2001. p. 125-35.

24. Tan CB. Intermarriage and the Chinese Peranakan in Southeast Asia. In: Suryadinata L, editor. Peranakan Chinese in a globalizing Southeast Asia. Singapore: Chinese Heritage Centre; 2010.
25. Hussin N. Trade and society in the Straits of Melaka: Dutch Melaka and English Penang. Singapore: NUS Press; 2007. p. 1780-830.

26. Lim BS. Distinctly Peranakan Hokkien. Peranakan. 2009;1:14.

27. Yoshino K. Malaysian cuisine: a case of neglected culinary globalisation. In: Farrer J, editor. Globalization, food and social identities in the Asia Pacific region. Tokyo: Sophia University Institute of Comparative Culture; 2010. p. 1-15.

28. Hoo R. Chronicling Nyonya cuisine. 2017. https://penangmonthly.com/ article.aspx?pageid=114\&name=chronicling_nyonya_cuisine. Accessed 10 Nov 2018.

29. Ong H. Visit Penang. 2010. http://www.visitpenang.gov.my/portal3. Accessed 21 Nov 2018.

30. Peranakan Life. Nyonya cuisine. n.d. http://www.peranakanlife.com/babanyonya-culture/peranakan-food/nyonya-cuisine. Accessed 22 Nov 2018.

31. Tan CB. The Baba of Melaka. Petaling Jaya: Pelanduk Publications; 1988.

32. Tan CB. Nyonya cuisine: Chinese, non-Chinese and the making of a famous cuisine in Southeast Asia. In: Cheung SCH, Tan CB, editors. Food and foodways in Asia: resource, tradition and cooking. Oxon: Routledge; 2007.

33. Sidek N. Pembudayaan makanan Malaysia. Sambutan hari makanan sedunia kali ke-25, Kementerian Pertanian dan Industri Asas Tani Malaysi. Kuala Lumpur: Agriculture Bank of Malaysia; 2005.

34. Karim S, Halim N. The structure of Penang street food culture in Malaysia. In: CDCV C, Companion M, Marras SR, editors. Street food: culture, economy, health and governance. New York: Routledge; 2014.

35. Wong J. Singapore baba vs Penang nonya. 2015. http://www.star2. com/food/food-news/2015/08/27/singapore-baba-vs-penang-nonya. Accessed 15 Oct 2018

36. Eckhardt R. Food \& drinks. In: Bindloss J, Brash C, editors. Kuala Lumpur. 1st ed. Kuala Lumpur: Lonely planet; 2008. p. 42-53.

37. Poh LY. Melaka. 2010. http://www.abc.net.au/tv/pohskitchen/stories/s29363 07.htm. Accessed 22 Nov 2018

38. Khor N, Khoo SN, Loh WL, Yeoh SG. Penang and its region: the story of an Asian Entrepôt. Singapore: NUS Press; 2009.

39. Shushan L. Has the 'soul' gone out of modern Peranakans?. 2017. http:// www.channelnewsasia.com/news/singapore/has-the-soul-gone-out-ofmodern-peranakans/3493862.html. Accessed 26 Sept 2018

40. Albattat AR, Asmara L, Bakri N, Norzaman N. The awareness of Baba Nyonya food amongst culinary arts students in Management and Science University. Almatourism - J Tour Cult Territorial Dev. 2017;8:117-35. https://doi.org/10. 6092/issn.2036-5195/6784

41. Ooi KG. Eclectic sociocultural traditions of the Baba Nyonya of George Town, Penang, Malaysia. Suvannabhumi. 2017;9(2):51-89.

42. Lim C, and Sekaran R. Baba Nyonya convention aims to uphold precious heritage. 2017. https://www.thestar.com.my/metro/metro-news/2017/11/29/ telling-the-peranakan-story-baba-nyonya-convention-aims-to-upholdprecious-heritage. Accessed 29 Nov 2018

\section{Publisher's Note}

Springer Nature remains neutral with regard to jurisdictional claims in published maps and institutional affiliations.

Ready to submit your research? Choose BMC and benefit from:

- fast, convenient online submission

- thorough peer review by experienced researchers in your field

- rapid publication on acceptance

- support for research data, including large and complex data types

- gold Open Access which fosters wider collaboration and increased citations

- maximum visibility for your research: over $100 \mathrm{M}$ website views per year

At BMC, research is always in progress.

Learn more biomedcentral.com/submissions 